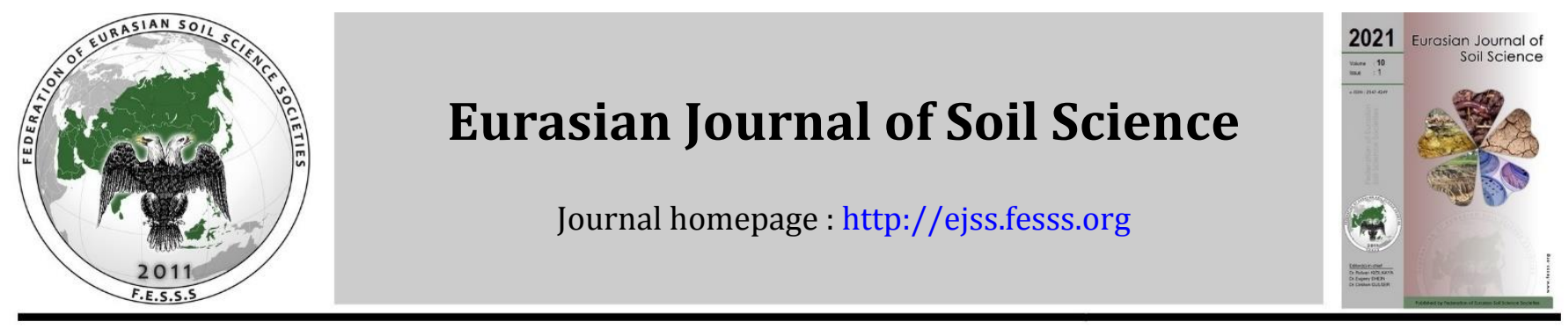

\title{
Hygienization assessment during heap co-composting of Turkey manure and olive mill pomace
}

\author{
Rachid Aboutayeb a,*, Soufiane El-mrini b, Abdeljalil Zouhri b, \\ Omar Idrissi a, Khalid Azim c \\ a National Institute of Agricultural Research (INRA), Regional Center, Settat, Morocco \\ b Hassan $1^{\text {st }}$ University, College of Sciences and Techniques, Settat, Morocco \\ c National Institute of Agricultural Research (INRA), Regional Center of Agadir, Morocco
}

\section{Article Info}

Received : 10.02 .2021

Accepted : 09.07.2021

Available online : 15.07 .2021

\section{Author(s) \\ R. Aboutayeb * \\ S. El-mrini \\ A. Zouhri \\ O. Idrissi \\ K. Azim}

* Corresponding author

\begin{abstract}
This study aimed to investigate the co-composting time effectiveness as well as the effect of the initial Carbon/Nitrogen ratio $(\mathrm{C} / \mathrm{N}) \mathrm{i}$ variation on the hygienization of olive pomace and turkey manure. Six different heaps, at 3 levels of $(\mathrm{C} / \mathrm{N})$ i ratios: 20, 22 and 28, were installed and monitored during 6 months and assessed at three steps: At the beginning, the end of thermophilicphase and the end of curing-phase. The microbial monitoring concerned 5 microbial pathogens contents, used as hygiene microbial indicators, namely: Sulphite-Reducing Anaerobes (SRA), Escherichia Coli (E. Coli), Total Aerobic Mesophilic Flora (TAMF), Staphylococci, and Salmonella spp. Initially, the mixtures showed high TAMF and Staphylococci loads. Meanwhile, SRA and E. coli populations were relatively low and Salmonella spp. was not detected. The microbial assessment showed a significant effect of composting time on the reduction of pathogens load, except for SRA where its population has increased significantly, while the $(\mathrm{C} / \mathrm{N})_{\mathrm{i}}$ had a non-significant effect on pathogen content of the end-product. The final values expressed as colony-forming unit per gram $\left(\mathrm{CFU} \mathrm{g}{ }^{-1}\right)$, were as follow: Sulfite-reducing Anaerobes $\left(\leq 3.1 \times 10^{3} \mathrm{CFU} \mathrm{g}^{-1}\right), \mathrm{E}$. Coli germ used as an indicator of faecal contamination $\left(<4 \times 10^{1} \mathrm{CFU} \mathrm{g}^{-1}\right)$, Total aerobic mesophilic flora ( $\left.\leq 1.4 \times 10^{6} \mathrm{CFU} \mathrm{g}^{-1}\right)$, Staphylococci $\left(<10 \mathrm{CFU} \mathrm{g}^{-1}\right)$ and non-detection of Salmonella spp. Finally, the seed germination tests were carried out on three different seeds: lentils (Lens culinaris), barley (Hordeum vulgare) and durum wheat (Triticum turgidum) showed that the use of the compost extract is favourable for seed germination with germination index (GI\%) values exceeding 85\%. These results confirm the non-phytotoxicity and maturity of the composts.
\end{abstract}

Keywords: Sanitation, pathogens, poultry manure, microbial hazard, germination index, olive by-products.

(C) 2021 Federation of Eurasian Soil Science Societies. All rights reserved

\section{Introduction}

Agro-food industries generate a considerable amount of organic wastes. They can be recycled as organic amendments after biological treatments (Tortosa et al., 2019). Nowadays, the rapid increase of biowaste production has become one of the most crucial issues in most countries around the world (Azim et al., 2017). Besides, intensive agricultural activities lead to soil fertility depletion, worsens soil erosion, and causes organic matter content reduction (Ramli et al., 2020). The olive crop is one of the main cultivation in Morocco and also in several Mediterranean countries and its socio-economic role is well known. Thus, olive production causes a serious environmental issue through the by-products generated from olive factories (Toledo et al., 2020). The three-phase system used for olive oil production generates huge amounts of by- 
products, namely olive mill wastewater (OMW) and olive mill pomace (OMP) within few months in a year according to Roig et al. (2006).

On the other hand, throughout the last decades, the poultry livestock has increased significantly in most countries, which has led to an increase in poultry manure production and has increased considerably the amount of all organic solid by-products and wastewaters (Assess et al., 2019; Toledo et al., 2020). According to Aboutayeb (2015), in the Chaouia-Ouardigha region in Morocco, quite 300,000 tons of turkey manure (TM) are produced yearly. The number of turkey livestock farms is up to 220 production units and the production capacity exceeds 5 million turkeys per breeding cycle (Aboutayeb, 2015). These intensive livestock systems cause ecological problems due to the production of huge amounts of manure, the spread of microbial pathogens and the release of putrid odours (Heinonen-Tanski et al., 2006).

While olive pomace is not usually associated with the risk of microbial pathogens, poultry manure could be a source of microbial hazard when it is spread as an organic amendment without former treatment. It contains several human pathogens species like Escherichia Coli, Clostridium, Listeria and Salmonella (Chen et al., 2014). Moreover, it provides favorable conditions for the proliferation of microbial pathogens, which worsens environmental pollution (Li et al., 2016).

In this regard, according to Bustamante et al. (2008), composting is defined as a biological process occurring in an aerobic environment leading to organic materials stabilisation and heat production. Composting has been presented as a promising technology and environmentally friendly technique to manage and recycle these biowastes, to obtain a quality compost used as an organic amendment soil fertility improvement (Azim et al., 2018; Assess et al., 2019). Among the various biological treatments, composting is perceived to be among the most promising practices due to its low cost and effectiveness to produce stable organic amendments according to de Mendonça Costa et al. (2016) and Soobhany et al. (2017). These end-products, called composts, could be used as organic amendments able to enhance soils physicochemical and biological properties (Chowdhury et al., 2013; Tortosa et al., 2019). Composting process, as biological treatment, could be used for biowastes processing to reduce its pathogenic potential (El Fels et al., 2014; Assess et al., 2019). Actually, it is a widely accepted technique for organic waste recycling into a stable organic material, with low pathogens loads and phytotoxicity. Compost is applied as an organic fertilizer and soil amendments to enhance soil fertility parameters (Huang et al., 2006; Toledo et al., 2020) and increase plant growth and yield production (Bustamante et al., 2008).

Hence, the biowaste reuse as compost on agricultural soils can play a vital role in increasing the sustainability of agricultural practices, especially in Mediterranean countries where soil organic matter (SOM) is generally low as mentioned by Assess et al (2019). Indeed, soils of semi-arid rainfed areas, such as those of the West-Asia and North-Africa regions have less than 1.5\% SOM content (Azim et al., 2017; Aboutayeb et al., 2020).

Depending on the composting process monitoring and the raw material origin, composts may also contain pathogenic microorganisms (Bustamante et al, 2008). Instead, the raw manure or immature compost spreading can induce pathogenic microorganism dissemination according to Millner et al. (1994) and Beffa et al. (1996) such as Salmonella spp., Listeria monocytogenes and E. coli, (Zhao et al., 1995; Islam et al., 2005; Soobhany et al., 2017). Moreover, the composting process improperly monitored can be a vector of several pathogens species initially present in raw organic waste or those resulting from the risk of re-proliferation during composting (Chen et al., 2014). Hassen et al. (2001) and Bustamante et al. (2008) have registered the proliferation of Shigella, Enterobacter, Yersinia and Streptococci which could cause infections diseases for farmers and compost handlers. . Actually, growing demand for sanitized compost is observed which reflects the increased interest in the food safety and environmental issues (Pandey et al., 2016; Soobhany et al., 2017). In certain cases, the remaining pathogenic organisms in a compost pile has been attributed to 3 main factors: inequal heating temperatures among different parts of the compost heap: The surface, the middle and the bottom of the piles (Aboutayeb, 2015); Mixtures inadequately homogenized as mentioned by Elving et al. (2010), and cross-contamination due to infected working tools (Soobhany et al., 2017). Hygiene microbial indicators, such as faecal coliforms, E. coli and streptococci are generally monitored during the composting process to ensure compost quality production (Bustamante et al., 2008; Aboutayeb, 2015). The subsistence of pathogenic populations in compost piles remains less explored (Soobhany et al., 2017). Faecal coliforms are generally associated with the animal faeces such as poultry manure (Aboutayeb et al., 2013); this is why regulations have adopted fecal coliforms, especially in E. coli, as an indicator of potential fecal contamination to assess the hygienic quality of the final compost (Soobhany et al., 2017). Although the composting process is potentially effective to reduce pathogens loads and thus producing a sanitized 
composts (Soobhany et al., 2017), data on the relationship between pathogen reduction and composting duration remains unsettled and needs more attention. This study aims to assess the effect of the initial C/N ratio and Treatment-time of co-composting on the microbial characteristics of the final compost concerning different human pathogens and microbial groups used as hygienic microbial indicators.

\section{Material and Methods}

\section{Raw materials}

The turkey manure used to carry out this study was collected and transported to the composting experiment site from three Turkey farms located in the immediate vicinity of Settat province in North-West of Morocco. The composting site is located in the experimental station of Sidi Elaidi (altitude $230 \mathrm{~m}, 33.17^{\circ} \mathrm{N}, 7.40^{\circ} \mathrm{W}$ ) belonging to the National Institute of Agricultural Research (INRA-Morocco). We have taken six composite samples for microbial analysis. The Olive mill pomace (OMP) was collected from a three-phase artisanal crushing unit (Maasras) in the Settat region. The durum wheat straw was used as a bulking agent for the composting process. Six heaps were prepared to obtain the initial C/N of 20, 22 and 28 in duplicate (2 heaps for each ratio) (Table 1). C/N was calculated using the formula OC(\%)/TN(\%) where OC(\%) = OM(\%)/1.73 (Table2).

Table 1. Composition (weight/weight) and (C/N)i of different mixtures

\begin{tabular}{cccccccc}
\hline Heaps & $\begin{array}{c}\text { Durum } \\
\text { wheat straw }\end{array}$ & $\begin{array}{c}\text { Turkey } \\
\text { manure }\end{array}$ & $\begin{array}{c}\text { Olive mill } \\
\text { pomace }\end{array}$ & C/N & Height (m) & Width (m) & Length (m) \\
\hline H1 & $10.0 \%$ & $26.4 \%$ & $63.6 \%$ & 20 & 1.2 & 1.3 & 1.5 \\
H2 & $10.0 \%$ & $26.4 \%$ & $63.6 \%$ & 20 & 1.2 & 1.3 & 1.5 \\
H3 & $60.0 \%$ & $10.0 \%$ & $30.0 \%$ & 28 & 1.5 & 1.4 & 1.4 \\
H4 & $60.0 \%$ & $10.0 \%$ & $30.0 \%$ & 28 & 1.5 & 1.4 & 1.8 \\
H5 & $20.0 \%$ & $20.0 \%$ & $60.0 \%$ & 22 & 1.6 & 1.4 \\
H6 & $20.0 \%$ & $20.0 \%$ & $60.0 \%$ & 22 & & 1.8 \\
\hline
\end{tabular}

\section{Composting process}

Olive mill pomace and turkey manure were added to the durum wheat straw and the heaps were moistened if necessary and composted in aerobic conditions. The experiment of composting is carried out for six months. During the composting process, the heaps have been manually turned. Heap temperatures monitoring was carried out using a compost thermometer. A sample from each heap was collected in sterile plastic bags to serve for physicochemical and microbial analysis. The Organic carbon, organic matter and nitrogen contents properties of composts, at the initial and final time, are shown in Table 2.

Table 2. Physicochemical properties of composts at the initial and final time (TNK: total nitrogen, OM: organic matter, $\mathrm{C} / \mathrm{N}$ : Carbon to nitrogen ratio).

\begin{tabular}{|c|c|c|c|c|c|c|c|c|c|c|c|c|}
\hline & \multicolumn{2}{|c|}{ H1 } & \multicolumn{2}{|c|}{$\mathrm{H} 2$} & \multicolumn{2}{|c|}{ H3 } & \multicolumn{2}{|c|}{$\mathrm{H} 4$} & \multicolumn{2}{|c|}{ H5 } & \multicolumn{2}{|c|}{ H6 } \\
\hline & Initial & Final & Initial & Final & Initial & Final & Initial & Final & Initial & Final & Initial & Final \\
\hline \multirow{2}{*}{ TNK (\%) } & $1.82 \pm$ & $2.26 \pm$ & $1.84 \pm$ & $2.77 \pm$ & $1.36 \pm$ & $2.58 \pm$ & $1.21 \pm$ & $2.81 \pm$ & $1.65 \pm$ & $2.82 \pm$ & $1.63 \pm$ & $2.66 \pm$ \\
\hline & 0.15 & 0.03 & 0.08 & 0.06 & 0.06 & 0.03 & 0.02 & 0.01 & 0.12 & 0.05 & 0.07 & 0.00 \\
\hline \multirow{2}{*}{ OM (\%) } & 61.72 & 43.66 & 58.96 & 58.58 & 66.37 & $54.1 \pm$ & 58.96 & 64.76 & 62.65 & 54.95 & 59.04 & 50.31 \\
\hline & \pm 0.90 & \pm 0.98 & \pm 0.70 & \pm 1.31 & \pm 0.13 & 1.31 & \pm 0.31 & \pm 1.75 & \pm 0.58 & \pm 0.11 & \pm 0.39 & \pm 2.30 \\
\hline \multirow{2}{*}{$\mathrm{C} / \mathrm{N}$} & 19.73 & 11.26 & 18.65 & 12.26 & 28.34 & 12.15 & 28.17 & 13.38 & 22.10 & 11.30 & 21.02 & 10.97 \\
\hline & \pm 1.88 & \pm 0.4 & \pm 0.59 & \pm 0.54 & \pm 1.36 & \pm 0.43 & \pm 0.22 & \pm 0.31 & \pm 1.76 & \pm 0.22 & \pm 0.77 & \pm 0.50 \\
\hline
\end{tabular}

\section{Microbial Analysis}

Microbial analyses were performed on the enumeration of 5 microorganisms considered as hygienic microbial indicators. The assessment of microorganism loads was expressed in colony-forming units per gram (CFU g-1). The samples were analyzed in three stages: S1 (at the beginning of composting), S2 (after 3 and 6 weeks of composting for heaps 5,6 and heaps 1,2,3,4 respectively) and S3 (at the end of the composting experiment). The Total Aerobic Mesophilic Flora (TAMF) density was determined using Plate Count Agar (PCA) medium and incubation at $30^{\circ} \mathrm{C}$ for $72 \mathrm{~h}$ (ISO 4833-1:2013). E. coli was assessed using the tryptone-bile-glucuronide medium, incubation at $44 \pm 1^{\circ} \mathrm{C}$ for $18 \mathrm{~h}$ to $24 \mathrm{~h}$. (ISO 16649-2:2001). Staphylococcus aureus load was determined using rabbit plasma fibrinogen agar medium, then incubation at $37^{\circ} \mathrm{C}$ for $24 \mathrm{~h}$ (ISO 6888-2:1999). Sulfite-reducing bacteria (characterized by typical black coloured colonies) were incubated under anaerobic conditions on agar plates using an iron-sulfite medium, then incubated at $37 \circ \mathrm{C} \pm 1^{\circ} \mathrm{C}$ for $24 \mathrm{~h}$ to $48 \mathrm{~h}$ (ISO 15213:2003). Finally, the determination of Salmonella presence was carried out, in $25 \mathrm{~g}$ sample inoculated to buffered peptone water and incubated at $37^{\circ} \mathrm{C} \pm 1^{\circ} \mathrm{C}$ for $18 \mathrm{~h} \pm 2 \mathrm{~h}$, isolated then identified and confirmed following the protocol of ISO 6579-1:2017/AMD 1:2020. 


\section{Phytotoxicity test and germination index (GI)}

The phytotoxicity test is based on the principle of the compost aqueous extract phytotoxicity towards the tested seeds. It involves placing the seeds of three different species (Durum wheat (Triticum turgidum), Barley (Hordeum vulgare) and Lentil (Lens culinaris), in a series of Petri dishes with filter paper impregnated with increasing doses of the compost extract: 25\%, 50\%, 75\% and 100\% (v/v) (three repetitions for each treatment). Another set of control (without compost aqueous extract) is prepared with distilled water and its germination index is considered as $100 \%$ for relative comparison with the treatments. The Petri dishes are placed in the germination chamber for 5 days at a temperature of $25^{\circ} \mathrm{C}$ and relative humidity of 85 to $90 \%$. After 3 days the number of seeds germinated per petri dish was determined. The phytotoxicity levels of the compost extracts were determined according to a standard method (Zucconi et al., 1981). Index Germination was calculated using the following formula:

$$
I G=\begin{array}{lll}
(\mathrm{Nmgg} * \mathrm{Lr}) \\
\text { Nmggt } * \text { Lrt }
\end{array} \quad \text { Where } \quad \begin{aligned}
& \text { Nmgg } \\
& \text { Lr }
\end{aligned} \begin{aligned}
& \text { : Number of germinated seeds; } \\
& \text { Nmggt } \\
& \text { Lrt }
\end{aligned} \quad \begin{aligned}
& \text { : Number of germinated seeds of the control; } \\
& \text { : Average length of the witness root. }
\end{aligned}
$$

\section{Statistical Analysis}

The effect of the factors studied ( $\mathrm{C} / \mathrm{N}$ ratio and Time) on the evolution of microbial populations was evaluated by ANOVA 2 and Tukey's test. The results were carried out using SPSS software, Version 20.

\section{Results and Discussion}

\section{Temperature monitoring}

Temperature is one of the major parameters to assess the progress of the composting process as it indicates the rate of microbial activity (Manu et al., 2019). Many authors consider $45^{\circ} \mathrm{C}$ as the temperature limit between the mesophilic and thermophilic phase during composting (Albrecht, 2007; Pujol, 2012). A temperature above $45^{\circ} \mathrm{C}$ can hygienize the heaps by reducing pathogens loads (Aboutayeb et al., 2013). All the heaps have recorded (Figure 1) thermophilic phases with maximum temperatures of 62, 57.3, 60.1, 59.6, 56.6 and $61.3^{\circ} \mathrm{C}$ for heaps 1 to 6 respectively, indicating organic matter biodegradation. The short periods of the thermophilic phase characterized the heaps with a lower proportion of straw and low initial C/N (H1 and H2) who reached the thermophilic phase faster due to their high manure content, and therefore high initial microbial load. After thermophilic phase, the six heaps have entered the maturation phase where the temperature tends to the ambient one indicating the end of the composting process. There is a similarity between the temperature curves of the heaps with the same composition (H1, H3 and H5 with H2, H4 and H6 respectively).

\section{Evolution of the microbial parameters}

At the start, the initial mixtures showed a high load of Staphylococci and TAMF populations, due probably to non-compliance with good hygiene practices in the Maasras (Rouas et al., 2015) and given that TM is considered as natural host for many microbes (Bustamante et al., 2008). However, all the mixtures recorded no presence of Salmonella even if the manure is a natural host, which proves good hygiene control in the livestock house (Aboutayeb, 2015).

\section{Sulphite reducers Anaerobes (SRA)}

Several studies have focused on the pathogenic density decay as one of the most important factors through composting process according to Gale (2004) or after compost spreading on agricultural soils, for healthy risks assessment (Soobhany et al., 2017). The presence of Clostridium bacteria, a pathogenic SRA germ, can be used as a suitable indicator for other faecal pathogens (Bustamante et al., 2008). Except for H2, all the heaps recorded an increase at S2 of composting time (Table 3). Then, H1, H3, H4 and $\mathrm{H} 6$ recorded a reduction at the end of composting while $\mathrm{H} 2$ and $\mathrm{H} 5$ recorded a slight increase in SRA by the end of the process. The statistical test shows that only the composting time factor has a significant effect on the increase in SRA load but only between the S1 and S2 composting stages. The final reduction was not significant which is unusual for SRA considered as a strict anaerobic germ. It could be explained by the presence of certain SRA species that tolerate oxygen presence and able to generate ATP in an aerobic environment, or capable to reduce nitrates (Loubinoux, 2001). The final reduction of SRA, even if it is not significant, can be explained by the scarcity of labile organic matter during the curing phase, the aerobic conditions and the presence of nitrates (Aboutayeb, 2015). 

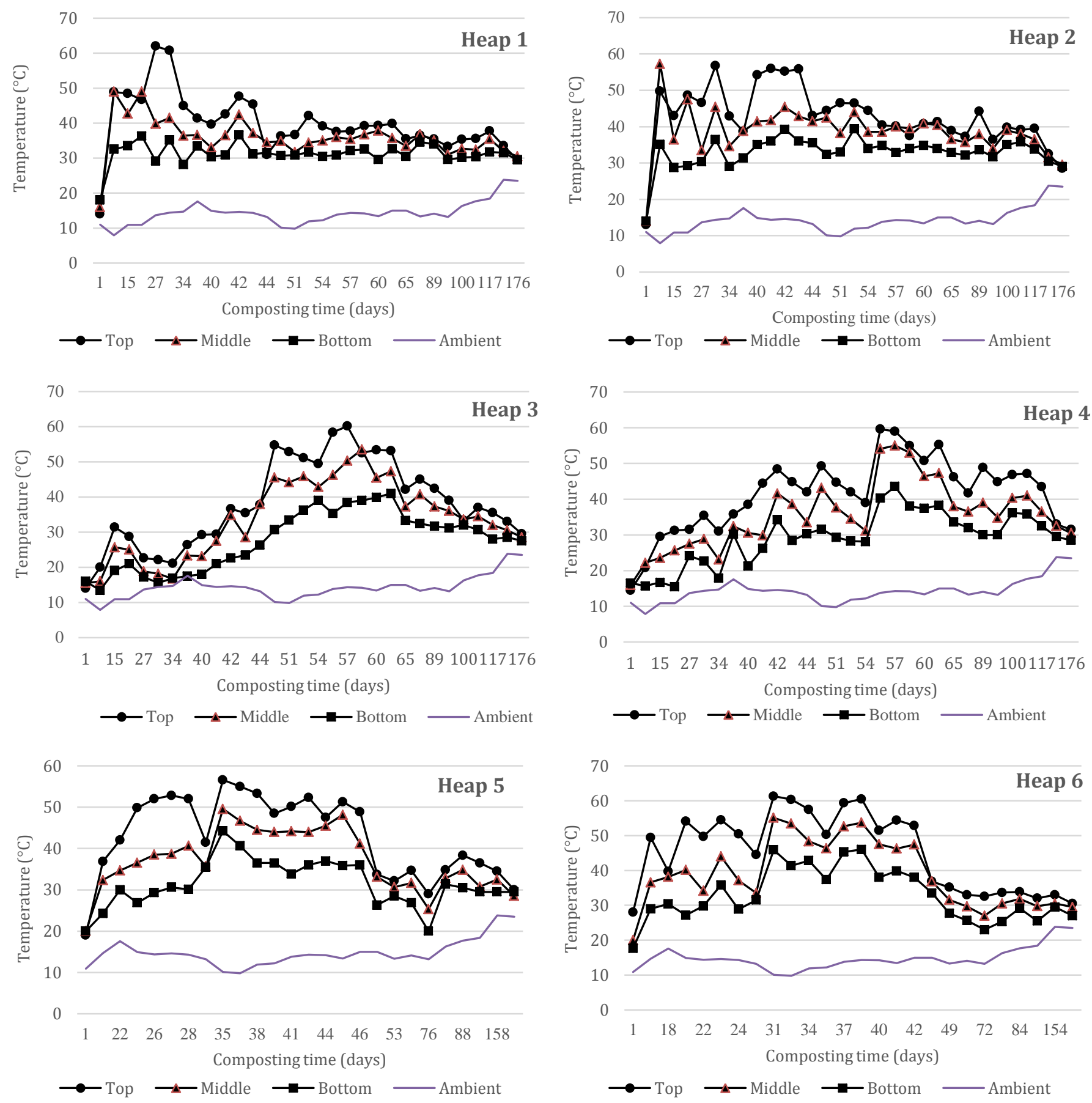

Figure 1. Temperature evolution during co-composting of olive pomace with turkey manure

The SRA loads in all heaps remain above $10^{3} \mathrm{CFU} \mathrm{g-1}$. This result is consistent with those found by Bustamante et al. (2008) who mentioned that there is no enough hygienization in composting piles to ensure the total elimination of Clostridium. This result could be explained by the fact that Clostridium bacteria show resistance to several adverse conditions and are among the heat resistant bacteria as mentioned by Juneja and Marmer (1998) and Payment (1999). However, the distribution of SRA makes challenging the production of free-Clostridium composts even in aerobic conditions (Juneja et al., 2003; Bustamante et al., 2008). This resistance could be explained by spores ability to survive in harsh conditions and the remaining anaerobic spaces leading to SRA growth (Böhnel and Lube, 2000; Jones and Martin, 2003; Pourcher et al., 2005). These results are better than those found by Bustamante et al. (2008) who found higher levels of SRA in turned piles, in general exceeding $10^{4} \mathrm{CFU} \mathrm{g}^{-1}$. These findings may be due to higher temperature values, during the thermophilic phase, reached in turning heaps and thus a more effective elimination of SRA have been recorded. 
Table 3. Monitoring of SRA and E.Coli content during the composting process. (S1 (at the beginning of composting), S2 (after 3 and 6 weeks of composting for heaps 5,6 and heaps 1,2,3,4 respectively) and S3 (at the end of the composting experiment)

\begin{tabular}{|c|c|c|c|c|c|c|}
\hline \multirow{2}{*}{ Heaps } & \multicolumn{3}{|c|}{ SRA } & \multicolumn{3}{|c|}{ E.Coli } \\
\hline & S1 & $\mathrm{S} 2$ & S3 & S1 & $\mathrm{S} 2$ & S3 \\
\hline H1 & $2.4 \times 10^{2}$ & $2.10 \times 10^{4}$ & $2.00 \times 10^{3}$ & $2.0 \times 10^{2}$ & $1.90 \times 10^{4}$ & $<10$ \\
\hline $\mathrm{H} 2$ & $2.4 \times 10^{2}$ & $1.0 \times 10^{2}$ & $2.40 \times 10^{3}$ & $2.0 \times 10^{2}$ & $3.30 \times 10^{5}$ & $<10$ \\
\hline H3 & $9.0 \times 10^{2}$ & $4.80 \times 10^{4}$ & $1.70 \times 10^{3}$ & $1.0 \times 10^{2}$ & $1.30 \times 10^{4}$ & $<10$ \\
\hline $\mathrm{H} 4$ & $9.0 \times 10^{2}$ & $1.60 \times 10^{4}$ & $2.90 \times 10^{3}$ & $1.0 \times 10^{2}$ & $7.8 \times 10^{2}$ & $<10$ \\
\hline H5 & $2.0 \times 10^{2}$ & $1.60 \times 10^{3}$ & $2.40 \times 10^{3}$ & $1.3 \times 10^{2}$ & $1.10 \times 10^{4}$ & $<10$ \\
\hline H6 & $2.0 \times 10^{2}$ & $1.10 \times 10^{5}$ & $3.10 \times 10^{3}$ & $1.3 \times 10^{2}$ & $5.70 \times 10^{5}$ & $<40$ \\
\hline
\end{tabular}

\section{Escherichia coli}

E. coli as an emerging pathogen is the main faecal coliform microorganism. It is usually considered as the most important pathogen to investigate in all processes that use or integrate faecal materials (Déportes et al., 1998; Hess et al., 2004; Bustamante et al., 2008). The presence of coliform bacteria reflects the hygienic quality level of soil and water in the environment. Its utilization as a hygienic indicator could bring several benefits due to the high detection frequency and easy revelation in faecal materials compared to other pathogens (Hassen et al., 2001).

Generally, the monitoring of the composting process showed the same evolution for both E.coli and fecal coliforms bacteria (Le Minor, 1984). The $(\mathrm{C} / \mathrm{N})_{\mathrm{i}}$ factor had a non-significant effect on E.coli; while the composting-time factor recorded a significant effect. E.coli, considered a thermotolerant germ, is not considered heat-resistant. Its growth limit temperature is $45.5^{\circ} \mathrm{C}$ (Vernozy-Rozand and Roze, 2003). At composting time S2 (Table 3), E.coli increased in all the heaps, given the favourable temperature because all the heaps were still in the mesophilic phase except $\mathrm{H} 1$ where the temperature exceeded $45^{\circ} \mathrm{C}$ but for just one day.

At the end of composting, E.coli was almost eliminated in all the heaps. E.coli was removed in $\mathrm{H} 1$ even though its temperature was $<36.7^{\circ} \mathrm{C}$ from S2 until composting end, which may be in agreement with the findings of Larney et al. (2003) who concluded that more than $99.9 \%$ of E. coli was removed, during the first 7 days of composting, at temperatures ranging from 33.5 to $41.5^{\circ} \mathrm{C}$. The thermophilic temperature/time pairs of $\mathrm{H} 1$ to $\mathrm{H} 6$ were $\left(43.5-45.8^{\circ} \mathrm{C} / 4\right.$ days separately), $\left(43.6-46.6^{\circ} \mathrm{C} / 4\right.$ days), $\left(43.7-47.1^{\circ} \mathrm{C} / 14\right.$ days), (47$51.3^{\circ} \mathrm{C} / 6$ days), $\left(42.7-50.1^{\circ} \mathrm{C} / 11\right.$ days) and $\left(44.7-54.1^{\circ} \mathrm{C} / 14\right.$ days) respectively. These lethal time/ temperature pairs are in agreement with other studies findings: Total destruction of E.coli in manure at $45^{\circ} \mathrm{C}$ during 72 hours of composting (Lung et al., 2001), and 7-14 days at $67^{\circ} \mathrm{C}$ as stated by Johannessen et al. (2005). E. Coli regrowth was observed during the first weeks (between S1 to S2 time of composting) which could be usually attributed to recontamination phenomena or explained by the insufficiency of compost selfheating and composting time (Soobhany et al., 2017).

The reduction of Escherichia coli loads used as a faecal-contamination indicator was significant in all final heaps. The E. Coli population is compliant with the recommended limit $\left(10^{3} \mathrm{CFU} \mathrm{g}^{-1}\right)$ indicating the heap cocomposting efficiency (Ros et al., 2006; Aboutayeb, 2015). This significant decrease could be explained by both a high temperature occurring in the heaps and aerobic conditions (Semenov et al., 2011).

This decay was likely the result of the high temperatures (thermophilic phase between $43.5^{\circ} \mathrm{C}$ and $54.1^{\circ} \mathrm{C}$ in all the heaps). Similar conclusions have been recorded by Hess et al (2004), who mentioned a decline, then an increase of E.coli population at $50^{\circ} \mathrm{C}$. Other studies highlighted that even with temperatures reaching up to $66^{\circ} \mathrm{C}$, the elimination of E.coli is not complete. According to De Bertoldi et al (1983) and confirmed by Assess et al. (2019), during the thermophilic stage, the recommended temperature is ranging between 40 and $65^{\circ} \mathrm{C}$ and temperatures above $55^{\circ} \mathrm{C}$ are required to eliminate coliforms considered as thermotolerant microorganisms. An important decrease in the E.coli population was recorded after the thermophilic phase in all the heaps. This finding complies with several previous works that have shown the ability of the composting process to eliminate E. coli (Mainoo et al., 2009; Aira et al., 2011).

\section{TAMF}

The effectiveness of the composting-time factor was high on the reduction of TAMF, especially between S2 and the end of composting (Table 4). Initially, all the heaps showed a high density of TAMF. At S2 time of composting, the density of TAMF increased for all heaps, which is consistent with the work of El Fels (2015) who reported that mesophilic bacteria growth continues even at $50^{\circ} \mathrm{C}$. Then, TAMF was significantly reduced in the mature composts. This decrease was mainly due to the temperature increase during the thermophilic 
phase and the unfavourable conditions in the heap essentially due to the labile organic matter depletion" (Kalamdhad and Kazmi, 2009; Aboutayeb et al., 2013). The final density of TAMF which still quite important could be explained by its re-proliferation during the maturation phase characterized by the favorable temperature conditions for mesophilic microflora growth (El Fels et al., 2015).

Strict monitoring, especially of the temperature profile, should be performed to reduce contamination risks due to pathogens high loads essentially when raw animal material, considered as a natural host, was used. The outcomes of other studies were consistent with these results by the fact that mesophilic bacteria were predominant at the beginning of the co-composting process and their population remain around $10^{5}$ and $10^{6}$ CFU g-1 during the cooling phase (Hachicha et al., 2009; Assess et al., 2019).

Table 4. Monitoring of TAMF, Staphylococci and Salmonella content during the composting process (ND: not detected. D: detected)

\begin{tabular}{|c|c|c|c|c|c|c|c|c|c|}
\hline \multirow[t]{2}{*}{ Heaps } & \multicolumn{3}{|c|}{ TAMF } & \multicolumn{3}{|c|}{ Staphylococci } & \multicolumn{3}{|c|}{ Salmonella } \\
\hline & S1 & S2 & S3 & S1 & S2 & S3 & S1 & S2 & S3 \\
\hline H1 & $3.54 \times 10^{6}$ & $2.50 \times 10^{7}$ & $7.60 \times 10^{5}$ & $4.49 \times 10^{6}$ & $9.80 \times 10^{6}$ & $<10$ & ND & ND & ND \\
\hline $\mathrm{H} 2$ & $3.54 \times 10^{6}$ & $2.00 \times 10^{7}$ & $2.70 \times 10^{4}$ & $4.49 \times 10^{6}$ & $<10$ & $<10$ & ND & ND & ND \\
\hline H3 & $1.43 \times 10^{6}$ & $1.50 \times 10^{7}$ & $1.40 \times 10^{6}$ & $1.70 \times 10^{6}$ & $<10$ & $<10$ & ND & ND & ND \\
\hline $\mathrm{H} 4$ & $1.43 \times 10^{6}$ & $1.60 \times 10^{7}$ & $2.10 \times 10^{5}$ & $1.70 \times 10^{6}$ & $2.10 \times 10^{6}$ & $<10$ & ND & ND & ND \\
\hline H5 & $2.86 \times 10^{6}$ & $3.20 \times 10^{6}$ & $1.50 \times 10^{5}$ & $3.40 \times 10^{6}$ & $<10$ & $<10$ & ND & ND & ND \\
\hline H6 & $2.86 \times 10^{6}$ & $2.00 \times 10^{7}$ & $2.00 \times 10^{5}$ & $3.40 \times 10^{6}$ & $<10$ & $<10$ & ND & $\mathrm{D}$ & ND \\
\hline
\end{tabular}

\section{Staphylococci}

Staphylococci is considered an optional aero-anaerobic microorganism widely known as one of the main causes of food biological hazards such as toxic infections (Vernozy-Rozand et al., 2004; Bustamante et al., 2008). Staphylococci growth occur under a large pH interval (4-9.3), requires temperature ranging between $7^{\circ} \mathrm{C}$ and $46^{\circ} \mathrm{C}$ and water activity (Aw) above 0.84 in aerobic conditions (Lamprell, 2003). Table 4 shows that in all heaps, the $\mathrm{C} / \mathrm{N}$ factor has a no-significant effect on Staphylococci content while composting time has reduced significantly its load. It was almost eliminated by the end of the composting period (beneath $10 \mathrm{CFU}$ $\mathrm{g}^{-1}$ for all the heaps).

The number of Staphylococci increased during the bio-oxidative phase in $\mathrm{H} 1$ and $\mathrm{H} 4$ then decreased at the maturation phase in all the heaps (beneath $10 \mathrm{CFU} \mathrm{g}^{-1}$ ). These results could be explained by the temperature evolution (heating and cooling) in the bio-oxidative phase and scarcity of labile organic matter in addition to the competition with other microorganisms essentially fungi (molds and yeasts) present in the heaps. These results are in agreement with those found by Bustamante et al. (2008) where levels of Staphylococci detected were less than $3 \mathrm{CFU} \mathrm{g}^{-1}$ of compost. Some authors report that pathogens species could be inhibited by several compounds contained in the heap such as organic acids, ammonia and flavonoid compounds even though temperature remains the most effective factor (Ait Baddi et al., 2004; Hachicha et al., 2009).

These results are better than those found by Aboutayeb (2015) who concluded that the population of Staphylococci was significantly reduced through composting time; however, the remaining density (slightly higher than $10^{4} \mathrm{CFU} \mathrm{g}{ }^{-1}$ ) could be due to the ubiquitous character of Staphylococci. Despite successful composting, the sanitary hazard remains probable due to a potential staphylococcus regrowth, especially in the peripheral parts (Albrecht, 2007; Sidhu et al., 2001; Aboutayeb et al., 2013).

\section{Salmonella}

Salmonella is a pathogenic bacteria of high concern in farming (Jamieson et al., 2002). It is related directly to the compost hygienic quality according to Brinton Jr and Droffner (1994) and Yanko et al. (1995). The risk related to this pathogen is increased because of its fast growing and ubiquitous presence (Hassen et al., 2001).

Several studies have concluded the possibility of the presence of Salmonella during biowaste composting even if the required time-temperature pairs were reached (Pourcher et al., 2005; Millner et al., 2014). As mentioned by Bustamante et al. (2008), Salmonella was detected in all animal biowaste which explains its presence in the composting pile containing poultry manure as a raw material. Even though Salmonella is not among thermotolerant microorganisms, it could persist at a high temperature exceeding $50^{\circ} \mathrm{C}$ (Droffner et al., 1995).

The present work showed that Salmonella was completely absent in all the heaps by the end of the cocomposting process (Table 4). This result is in agreement with those found by Soobhany et al. (2017) who concluded that Salmonella spp. decreased below the detection limit (Less than 1 most probable number per sample of $4 \mathrm{~g}$ ). Similarly, it is consistent with the result of Aboutayeb (2015) who concluded the non- 
detection of Salmonella in all the heaps. In the sixth heap (H6), Salmonella was only detected at S2 of composting (Mesophilic phase). This finding is consistent with other studies which demonstrated that Salmonella spp. was able to regrow in compost, windrows as a post-contamination even if the composting process was well monitored (Erickson et al., 2010; Soobhany et al., 2017). The reason for the regrowth could be explained by the lack of homogeneous temperature profile in the heap or due to recontamination occurring through compost handling (PereiraNeto et al., 1986; Gerba et al., 1995). Other factors could also influence Salmonella growth particularly, nutrient availability and moisture content (Bustamante et al., 2008). As a consequence, the production of Salmonella free compost requires an effective and efficient composting process monitoring to avoid pathogens regrowth (Soobhany et al., 2017).

\section{Germination Index (GI)}

In order to assess the compost maturity, the phytotoxicity test is one of the most important criteria used for this purpose (Bargougui et al., 2019). It allows to state reliable conclusions about the potential importance of the end-product, compost, to be used as an alternative organic fertilizer on agricultural crops. The final composts were assessed to reveal their phytotoxic potential, through the germination indexes (GI\%) determination. Seeds of 2 cereals and a legume were used, Durum wheat, Barley and Lentils respectively.

The compost extracts were prepared from the six mature compost samples obtained from the studied process once finished. The compost extracts recorded quite good seeds germination and the recorded results were as follow: $101,42 \% \pm 20,32 \%, 112,22 \% \pm 15,74 \%$ and $92,29 \% \pm 18,43 \%$ for lentils, durum wheat and barley seeds respectively, thus indicating both the absence of any phytotoxic effect and so the maturity of the olive pomace and turkey manure final co-compost (Table 5).

Table 5. Germination index (GI) of lentils, durum wheat and barley at different doses of compost extract (v/v)

\begin{tabular}{|c|c|c|c|c|c|c|}
\hline & \multicolumn{2}{|c|}{ Lentils } & \multicolumn{2}{|c|}{ Wheat } & \multicolumn{2}{|c|}{ Barley } \\
\hline GI $25 \%$ & $99,70 \%$ & $\pm 35,84 \%$ & $124,37 \%$ & $\pm 2,69 \%$ & $95,90 \%$ & $\pm 36,03 \%$ \\
\hline GI $50 \%$ & $116,94 \%$ & $\pm \quad 17,61 \%$ & $109,11 \%$ & $\pm \quad 35,59 \%$ & $102,60 \%$ & $\pm \quad 11,47 \%$ \\
\hline GI $75 \%$ & $84,27 \%$ & $\pm \quad 3,38 \%$ & $103,09 \%$ & $\pm \quad 18,27 \%$ & $93,43 \%$ & $\pm 9,25 \%$ \\
\hline GI 100\% & $104,76 \%$ & $\pm 24,47 \%$ & $112,31 \%$ & $\pm \quad 6,42 \%$ & $77,25 \%$ & $\pm 16,99 \%$ \\
\hline GI average $(\%)$ & $101,42 \%$ & $\pm \quad 20,32 \%$ & $112,22 \%$ & $\pm \quad 15,74 \%$ & $92,29 \%$ & $\pm 18,43 \%$ \\
\hline
\end{tabular}

GI value exceeding $80 \%$ reflects the non-phytotoxicity effect of mature compost according to Hachicha et al. (2006) and Francou (2005). These high seeds germination indexes values could be due to the high quality of the obtained compost and seeds resistance to residual phytotoxic compounds indicating consistency with previous studies (Bargougui et al., 2019).

\section{Conclusion}

From a hygienic point of view, co-composting of TM and OMP could remarkably decrease, over 6 months follow-up, the pathogen loads in the end-product especially for TAMF, sulfite-reducing Anaerobes, E. Coli, and Staphylococci. Besides, the initial $\mathrm{C} / \mathrm{N}$ ratio has a no-significant effect on microorganism populations. Consequently, co-composting treatment has been demonstrated to be an effective and sustainable process for biowaste valorization and organic material sanitization. This study revealed that the co-composting technique could contribute effectively to transform poultry manures and industrial olive-oil by-products into a valuable resource. Aerobic heap co-composting made it possible to produce a sanitized and non-phytotoxic end-product that could be used as a soil organic amendment. This bioprocess has prevented contamination and reduced the density of all studied pathogenic microorganisms and improved the GI of all studied seeds (wheat, barley and lentil) leading to control of both sanitary and phytotoxic hazards associated with compost production from contaminated organic wastes. Additionally, achieving high thermal values during the bio-oxidative phase was revealed insufficient; it is also crucial to monitor the whole co-composting process to ensure a safe final compost with low pathogen contents leading to minimize the microbial hazards. This fact leads to the reduction of environmental issues due to the mismanagement of different biowastes composting and therefore contributes to the sustainability of agricultural practices. These findings could be completed by further studies focusing on composting process sanitation and contamination risk assessment, in order to contribute to a sustainable development policy capable to recycle and reuse agro-food by products.

\section{References}

Aboutayeb, R., 2015. Valorisation des fumiers de volailles de chair: Compostage, épandage et étude des effets des fumiers de volailles et leurs composts sur les propriétés physicochimiques du sol sous cultures de maïs fourrager et de menthe verte. Thèse de doctorat, Université Hassan I, Faculté des sciences et techniques, Settat, Maroc. [in French] 
Aboutayeb, R., Elgharous, M., Abail, Z., Elhari, M., Koulali, Y., 2013. Stabilization and sanitation of chicken litter by heap composting. International Journal of Engineering Research \& Technology (IJERT) 2(9): 529-534.

Aboutayeb, R., El Yousfi, B., El Gharras, O., 2020. Impact of No-Till on physicochemical properties of Vertisols in Chaouia region of Morocco. Eurasian Journal of Soil Science 9(2): 119-125.

Aira, M., Gómez-Brandón, M., González-Porto, P., Domínguez, J., 2011. Selective reduction of the pathogenic load of cow manure in an industrial-scale continuous-feeding vermireactor. Bioresource Technology 102(20): 9633-9637.

Ait Baddi, G., Alburquerque, J.A., Gonzálvez, J., Cegarra, J., Hafidi, M., 2004. Chemical and spectroscopic analyses of organic matter transformations during composting of olive mill wastes. International Biodeterioration \& Biodegradation 54 (1): 39-44.

Albrecht, R., 2007. Co-composting of sewage treatment plant sludge and green waste: new methodology for monitoring organic matter transformations. PhD Thesis. University of Law, Economics and Sciences-Aix-Marseille III, France. $189 \mathrm{p}$.

Assess, N., Farhat, W., Hamdi, M., Bouallagui, H., 2019. Large scale composting of poultry slaughterhouse processing waste: Microbial removal and agricultural biofertilizer application. Process Safety and Environmental Protection 124: 128-136.

Azim, K., Faissal, Y., Soudi, B., Perissol, C., Roussos, S., Alami, I.T., 2018. Elucidation of functional chemical groups responsible of compost phytotoxicity using solid-state 13C NMR spectroscopy under different initial C/N ratios. Environmental Science and Pollution Research 25: 3408-3422.

Azim, K., Komenane, S., Soudi, $\quad$ B., 2017. Agro-environmental assessment of composting plants in Southwestern of Morocco (Souss-Massa Region). International Journal of Recycling of Organic Waste in Agriculture 6: 107-115.

Bargougui, L., Guergueb, Z., Chaieb, M., Mekki, A., 2020. Co-composting of olive industry wastes with poultry manure and evaluation of the obtained compost maturity. Waste and Biomass Valorization 11 : 6235-6247.

Beffa, T., Blanc, M., Marilley, L., Lott, Fisher, J., Lyon, P.F., 1996. Taxonomic and metabolic microbial diversity during composting. In: The Sciences of Composting. de Bertoldi, M., Sequi, P., Lemmes, B., Papi, T. (Eds.). Blackie Academic and Professional, Glasgow, UK, pp. 149-161.

Böhnel, H., Lube, K., 2000. Clostridium botulinum and Bio-compost. A contribution to the analysis of potential health hazards caused by bio-waste recycling. Journal of Veterinary Medicine, Series B 47(10): 785-795.

Brinton Jr, W.F., Droffner, M.W., 1994. Microbial approaches to characterization of composting process. Compost Science \& Utilization 2(3): 12-17.

Bustamante, M.A., Moral, R., Paredes, C., Vargas-García, M.C., Suárez-Estrella, F., Moreno, J., 2008. Evolution of the pathogen content during co-composting of winery and distillery wastes. Bioresource Technology 99(15): 72997306.

Chen, Z., Jiang, X., 2014. Microbial safety of chicken litter or chicken litter-based organic fertilizers: A review. Agriculture 4: 1-29.

Chowdhury, A.K.M.M.B., Akratos, C.S., Vayenas, D.V., Pavlou, S., 2013. Olive mill waste composting: a review. International Biodeterioration \& Biodegradation 85: 108-119.

de Bertoldi, M.D., Vallini, G., Pera, A., 1983. The biology of composting: a review. Waste Management \& Research 1(2): 157-176.

de Mendonça Costa, M.S.S., Lorin, H.E.F., de Mendonça Costa, L.A., Cestonaro, T., Pereira, D.C., Bernardi, F.H., 2016. Performance of four stabilization bioprocesses of beef cattle feedlot manure. Journal of Environmental Management 181 : 443-448.

Déportes, I., Benoit-Guyod, J.L., Zmirou, D., Bouvier, M.C., 1998. Microbial disinfection capacity of municipal solid waste (MSW) composting. Journal of Applied Microbiology 85(2): 238-246.

Droffner, M.L., Brinton, W.F., Evans, E., 1995. Evidence for the prominence of well characterized mesophilic bacteria in thermophilic $\left(50-70^{\circ} \mathrm{C}\right)$ composting environments. Biomass and Bioenergy 8(3): 191-195.

El Fels, L., Ouhdouch, Y., Hafidi, M., 2015. Use of the co-composting time extract agar to evaluate the microbial community changes during the co-composting of activated sludge and date palm waste. International Journal of Recycling of Organic Waste in Agriculture 4: 95-103.

El Fels, L., Zamama, M., El Asli, A., Hafidi, M., 2014. Assessment of biotransformation of organic matter during cocomposting of sewage sludge-lignocelullosic waste by chemical, FTIR analyses, and phytotoxicity tests. International Biodeterioration \& Biodegradation 87: 128-137.

Elving, J., Ottoson, J., Vinnerås, B., Albihn, A., 2010. Growth potential of faecal bacteria in simulated psychrophilic/ mesophilic zones during composting of organic waste. Journal of Applied Microbiology 108(6): 1974-1981.

Erickson, M.C., Liao, J., Boyhan, G., Smith, C., Ma, L., Jiang, X., Doyle, M.P., 2010. Fate of manure-borne pathogen surrogates in static composting piles of chicken litter and peanut hulls. Bioresource Technology 101: 1014-1020.

Felipo, M.T., 1996. Compost as a source of organic matter in Mediterranean soils. In: The science of composting. De Bertoldi, M., Sequi, P., Lemmes, B., Papi, T. (Eds.). Blackie Academic and Professional, Glasgow. pp. 403-412.

Francou, C., Poitrenaud, M., Houot, S., 2005. Stabilization of organic matter during composting: Influence of process and feedstocks. Compost Science \& Utilization 13(1): 72-83.

Gale, P., 2004. Risks to farm animals from pathogens in composted catering waste containing meat. Veterinary Record 155(3): 77-82. 
Gerba, C.P., Huber, M.S., Naranjo, J., Rose, J.B., Bradford, S., 1995. Occurrence of enteric pathogens in composted domestic solid waste containing disposable diapers. Waste Management \& Research 13(4): 315-324.

Hachicha, S., Cegarra, J., Sellami, F., Hachicha, R., Drira, N., Medhioub, K., Ammar, E., 2009. Elimination of polyphenols toxicity from olive mill wastewater sludge by its co-composting with sesame bark. Journal of Hazardous Materials 161(2): 1131-1139.

Hachicha, S., Chtourou, M., Medhioub, K., Ammar, E, 2006. Compost of poultry manure and olive mill wastes as an alternative fertilizer. Agronomy for Sustainable Development 26(2): 135-142.

Harrison, E.Z., 2004. Hygienic Implications of Small-Scale Composting in New York State. Final Report of the Cold Compost Project. Cornell Waste Management Institute, Ithaca, NY. Available at [access date: 10.02.2021]: https://ecommons.cornell.edu/bitstream/handle/1813/40227/coldcompost.pdf\%3Bjsessionid\%3D2695D4A7 E7107BF98B9CA6CC353BAAEE?sequence\%3D2

Hassen, A., Belguith, K., Jedidi, N., Cherif, A., Cherif, M., Boudabous, A., 2001. Microbial characterization during composting of municipal solid waste. Bioresource Technology 80 (3): 217-225.

Heinonen-Tanski, H., Mohaibes, M., Karinen, P., Koivunen, J., 2006. Methods to reduce pathogen microorganisms in manure. Livestock Science 102(3): 248-255.

Hess, T.F., Grdzelishvili, I., Sheng, H., Hovde, C.J., 2004. Heat inactivation of E. coli during manure composting. Compost Science \& Utilization 12(4): 314-322.

Huang, G.F., Wu, Q.T., Wong, J.W.C., Nagar, B.B., 2006. Transformation of organic matter during co-composting of pig manure with sawdust. Bioresource Technology 97(15): 1834-1842.

Islam, M., Doyle, M.P., Phatak, S.C., Millner, P., Jiang, X.P., 2005. Survival of Escherichia coli 0157:H7 in soil and on carrots and onions grown in fields treated with contaminated manure composts or irrigation water. Food Microbiology 22(1): $63-70$.

ISO 15213:2003. Microbiology of food and animal feeding stuffs - Horizontal method for the enumeration of sulfitereducing bacteria growing under anaerobic conditions. Available at [access date: 10.02.2021]: https://www.iso.org/standard/26852.html

ISO 16649-2:2001. Microbiology of food and animal feeding stuffs - Horizontal method for the enumeration of betaglucuronidase-positive Escherichia coli - Part 2: Colony-count technique at 44 degrees C using 5-bromo-4chloro-3-indolyl beta-D-glucuronide. Available at [access date: 10.02.2021]: https://www.iso.org/standard/29824.html

ISO 4833-1:2013. Microbiology of the food chain - Horizontal method for the enumeration of microorganisms - Part 1: Colony count at $30^{\circ} \mathrm{C}$ by the pour plate technique. Available at [access date: 10.02.2021]: https://www.iso.org/standard/53728.html

ISO 6579-1:2017/AMD 1:2020. Microbiology of the food chain - Horizontal method for the detection, enumeration and serotyping of Salmonella - Part 1: Detection of Salmonella spp. - Amendment 1: Broader range of incubation temperatures, amendment to the status of Annex D, and correction of the composition of MSRV and SC. Available at [access date: 10.02.2021]: https://www.iso.org/standard/76671.html

ISO 6888-2:1999. Microbiology of food and animal feeding stuffs - Horizontal method for the enumeration of coagulasepositive staphylococci (Staphylococcus aureus and other species) - Part 2: Technique using rabbit plasma fibrinogen agar medium. Available at [access date: 10.02.2021]: https://www.iso.org/standard/25571.html

Jamieson, R.C., Gordon, R.J., Sharples, K.E., Stratton, G.W., Madani, A., 2002. Movement and persistence of fecal bacteria in agricultural soils and subsurface drainage water: a review. Canadian Biosystems Engineering 44: 11-19.

Johannessen, G.S., James, C.E., Allison, H.E., Smith, D.L., Saunders, J.R., McCarthy, A.J., 2005. Survival of a Shiga toxinencoding bacteriophage in a compost model. FEMS Microbiology Letters 245(2): 369-375.

Jones, P., Martin, M., 2003. A review of the literature on the occurrence and survival of pathogens of animals and humans in green compost. Research report. Institute for Animal Health, Compton, Newbury, Berkshire, RG20 7NN, UK. ISBN: 1-84405-063-7.

Juneja, V.K., Marmer, B.S., 1998. Thermal inactivation of Clostridium perfringens vegetative cells in ground beef and turkey as affected by sodium pyrophosphate. Food Microbiology 15: 281-287.

Juneja, V.K., Novak, J.S., Huang, L., Eblen, B.S., 2003. Increased thermotolerance of Clostridium perfringens spores following sublethal heat shock. Food Control 14: 163-168.

Kalamdhad, A.S., Kazmi, A.A., 2009. Effects of turning frequency on compost stability and some chemical characteristics in a rotary drum composter. Chemosphere 74(10): 1327-1334.

Lamprell, H., 2003. Production des entérotoxines dans les fromages en fonction de la diversité phénotypique et génétique des souches de Staphylococcus aureus. PhD Thesis .Université de Bourgogne France. 168p. [in French].

Larney, F.J., Yanke, L.J., Miller, J.J., McAllister, T.A., 2003. Fate of coliform bacteria in composted beef cattle feedlot manure. Journal of Environmental Quality 32(4): 1508-1515.

Le Minor, L., 1984. Escherichia coli. In: Bactériologie Médicale. Le Minor, L., Véron, M. (Eds.). Flammarion Médecine Sciences, Paris, pp. 240-353. [in French].

Li, F., Cheng, S., Yu, H., Yang, D., 2016. Waste from livestock and poultry breeding and its potential assessment of biogas energy in rural China. Journal of Cleaner Production 126: 451-460.

Loubinoux J., 2001. Les bactéries sulfato-réductrices humaines: caractérisation et pouvoir pathogène. Médecine humaine et pathologie. PhD Thesis. Université Henri Poincaré - Nancy 1. Français. [in French]. 
Lung, A.J., Lin, C.M., Kim, J.M., Marshall, M.R., Nordstedt, R., Thompson, N.P., Wei, C.I., 2001. Destruction of Escherichia coli 0157: H7 and Salmonella enteritidis in cow manure composting. Journal of Food Protection 64(9): 13091314.

Mainoo, N.O.K., Barrington, S., Whalen, J.K., Sampedro, L., 2009. Pilot-scale vermicomposting of pineapple wastes with earthworms native to Accra, Ghana. Bioresource Technology 100(23): 5872-5875.

Manu, M.K., Kumar, R., Garg, A., 2019. Decentralized composting of household wet biodegradable waste in plastic drums: Effect of waste turning, microbial inoculum and bulking agent on product quality. Journal of Cleaner Production 226: 233-241.

Millner, P., Ingram, D., Mulbry, W., Arikan, O.A., 2014. Pathogen reduction in minimally managed composting of bovine manure. Waste Management 34(11): 1992-1999.

Millner, P.D., Olenchock, S.A., Epstein, E., Rylander, R., Haines, M.D., Walker, J., Ooi, B. L., Horne, E., Maritato, M., 1994. Bioaerosols associated with compost facilities. Compost Science \& Utilization 2(4): 6-57.

Pandey, P.K., Cao, W., Biswas, S., Vaddella, V., 2016. A new closed loop heating system for composting of green and food wastes. Journal of Cleaner Production 133: 1252-1259.

Payment, P., 1999. Poor efficacy of residual chlorine disinfectant in drinking water to inactive waterborne pathogens in distribution systems. Canadian Journal of Microbiology 45(8): 709-715.

Pourcher, A.M., Morand, P., Picard-Bonnaud, F., Billaudel, S., Monpoeho, S., Federighi, M., Ferré, V., Moguedet, G., 2005. Decrease of enteric micro-organisms from rural sewage sludge during their composting in straw mixture. Journal of Applied Microbiology 99: 528-539.

Pujol, A., 2012. Modélisation du procédé de compostage-Impact du phénomène de séchage. PhD Thesis. Institut National Polytechnique de Toulouse. 268p. [in French].

Ramli, H., Daoud, S., Harouni, M.C., Elame, F., Azim, K., 2020. Effect of organic amendments on soil fertility of organic potato crop. Acta Horticulturae 1286: 155-162.

Roig, A., Cayuela, M.L., Sánchez-Monedero, M.A., 2006. An overview on olive mill wastes and their valorisation methods. Waste Management 26(9): 960-969.

Ros, M., García, C., Hernández, T., 2006. A full-scale study of treatment of pig slurry by composting: Kinetic changes in chemical and microbial properties. Waste Management 26(10): 1108-1118.

Rouas, S., Rahmani, M., El Antari, A., Baamal, L., Eddakir, K., 2015. Impact des conditions d'hygiène et de fabrication sur la dégradation de la qualité potentielle des huiles d'olive produites dans la zone de Moulay Driss Zerhoun. Revue Marocaine des Sciences Agronomiques et Vétérinaires 3(1): 45-52

Semenov, A.V., Overbeek, L.V., Termoshuizen, A.J., van Bruggen, AH.C., 2011. Influence of aerobic and anaerobic conditions on survival of Escherichia coli 0157:H7 and Salmonella enterica serovar Typhimurium in LuriaBertani broth, farm-yard manure and slurry. Journal of Environmental Management 92(3): 780-787.

Sidhu, J., Gibbs, R.A., Ho, G.E., Unkovich, I., 2001. The role of indigenous microorganisms in suppression of salmonella regrowth in composted biosolids. Water Research 35(4): 913-920.

Soobhany, N., Mohee, R., Garg, V.K., 2017. Inactivation of bacterial pathogenic load in compost against vermicompost of organic solid waste aiming to achieve sanitation goals: A review. Waste Management 64 : 51-62.

Toledo, M., Gutiérrez, M.C., Peña, A., Siles, J.A., Martín, M.A., 2020. Co-composting of chicken manure, alperujo, olive leaves/pruning and cereal straw at full-scale: Compost quality assessment and odour emission. Process Safety and Environmental Protection 139: 362-370.

Tortosa, G., Torralbo, F., Maza-Márquez, P., Aranda, E., Calvo, C., González-Murua, C., Bedmar, E.J., 2019. Assessment of the diversity and abundance of the total and active fungal population and its correlation with humification during two-phase olive mill waste ("alperujo") composting, Bioresource Technology 295: 122267.

Vernozy-Rozand, C., Mazuy-Chucradeut, C., Bavai, C., Richard, Y., 2004. Comparison of three immunological methods for detecting staphylococcal enterotoxins from food. Letters in Applied Microbiology 39(6): 490-494.

Vernozy-Rozand, C., Roze, S., 2003. Bilan des connaissances relatives aux Escherichia coliproducteurs de Shiga-toxines (STEC). French Food Safety Agency, Maisons-Alfort, France. 220p. Available at [access date: 10.02.2021]: https://www.anses.fr/fr/system/files/MIC-Ra-STEC.pdf [in French].

Yanko, W.A., Walker, A.S., Jackson, J.L., Libao, L.L., Garcia, A.L., 1995. Enumerating Salmonella in biosolids for compliance with pathogen regulations. Water Environment Research 67(3): 364-368.

Zhao, T., Doyle, M.P., Shere, J., Garber, L., 1995. Prevalence of enterohemorrhagic Escherichia coli 0157:H7 in a survey of dairy herds. Applied and Environmental Microbiology 61(4): 1290-1293.

Zucconi, F., Forte, M., Monaco, M., De Bertoldi, M., 1981. Biological evaluation of compost maturity. Biocycle 22 : $27-29$. 